Biol. Neonate 1981;39:I-IV

\title{
Contents, Vol. 39, 1981
}

\section{No. 1-2}

Enterobacteria of the Neonate. Normal Colonization and Antibiotic-Induced Selection Borderon, J.C.;Gold, F.; Laugier, J 1

Crypt Cell Renewal and Chemical Sympathectomy in the Pre-Closure Ileum of the Neonatal Rat Klein, R.M 8

Effect of Intrauterine Growth Retardation on the Activities of Fetal Intestinal Enzymes in Rats

Lebenthal, E.;Nitzan, ML; Lee, P.C.; Chrzanowski, B.L.; Krasner, J

Glycogen Reserves in the Subcutaneous Adipose Tissue and Energy Metabolism in Newborns of Diabetic

Mothers

Pfibylová, H.; Rázová, M

Pituitary Response to Bilateral Adrenalectomy, Metyrapone Treatment and Ether Stress in the Newborn

Rat

Hary, L.;Dupouy, J.-P.;Chatelain, A 28

Lipids and Lipoproteins in Maternal and Fetus Plasma in the Rat

Argiles; J.;Herrera, E 37

Maternal Nutrient Storage and Efficiency in Production of Fetal Brain Tissue in Rats

Zamenhof, S 45

Hemodynamic Response of the Pelvic Vascular Bed to Vasoactive Stimuli in Pregnant Sheep

Tabsh, K.; Nuwayhid, B.; Erkkola, R.; Zugaib, M.; Lieb, S.; Ushioda, E.; Brinkman, C.R.;

Assali,N.S 52

Noradrenergic Control of Blood Vessels in the Premature Lamb Fetus

Zınk, J.;VanPetten, G.R 61

Prematurity in the Rat. III. Effect of Oxygen Supply

Cuezva, J.M.; Medina, J.M 70

Metabolic Responses to Alanine in Small-for-Gestational Age Infants: Developmental Aspects Søvik, O.; Selvig, S.; Finne, P.H 78

Effect of Acute Nonsurgical Stress on Fetal and Maternal Plasma Glucose, Glucagon and Insulin Concentration in Sheep

Schreiner, R.L.; Lemons, J.A.;Gresham, E.L.;Nolen, P.A.; Bohnke, R.A.; Reyman, D.S 86

Development of Proteolytic Activity in Rabbit Fetal Intestine

Morin, P.-R.; Potier, M 91

Influence of Intrauterine Malnutrition on Brain Development: Alteration of Myelination

Bourre,J.M.; Morand,O.; Chanez,C; Dumont,O.; Flexor, M. A 96

Cellular Retinol Binding Protein during Postnatal Development of the Rat Small Intestine

Kylberg, H.K.;Ong, D.E.; Chytil, F 100

Uptake and Release of Energy Substrates, Oxygen, and Carbon Dioxide by the Hindlimb of the Fasting 
Infant Baboon

Levitsky, L.L.;Paton, J.B.; Fisher, D.E.;deLannoy, C.W 105

Contents Io

No. 3-4

Phototherapy in Gunn Rats. II. Further Calculations on the Effectivity of Different Irradiances

(Ebiii)

Wiese, G.; Ballowitz, L

Metabolic Activity of Developing Rat Lung

Hamosh, M.; Simon, M.R.; Mullon, D.K.; Hamosh, P

Oxytocin Concentrations during the Neonatal Period

Leake, R.D.; Weitzman, R.E.; Fisher, D.A 127

Effects of Diets with or without Folic Acid, with or without Methionine, on Fetus Development,

Folate

Stores and Folic Acid-Dependent Enzyme Activities in the Rat

Potier de Courcy, G.;Bujoli, J 132

Brown Fat Thermoregulation in Developing Hamsters (Mesocricetus auratus): a GDP-Binding Study

Sundin, U.; Herron, D.; Cannon, B 141

An Improved Technique for Perfusion of the Guinea Pig Placenta in situ Giving Viable

Conditions Demonstrated by Placental Transport of Amino Acids (L- and Z)-Alanine)

Kihlström, I.;Kihlström, J.E 150

A Longitudinal Study on Plasma Somatomedin Activity in Full-Term, Preterm and Small-for-

Gesta-

tional Age Newborns

Tatò, L.;DalMoro, A.;Piemonte, G.;Vigi, V.;Pizzo, P.;Volpato, S.;Gaburro, D 160

Fetal Rat Adrenal Gland Steroidogenesis in vitro in Prolonged Pregnancy

Klepac, R $\quad 165$

Detection of Proteins in Human Amniotic Fluid Using Two-Dimensional Gel Electrophoresis

Jones, M.I.; Spragg, S.P.; Webb, T 171

Effects of Maternal Caffeine Ingestion of Neonatal Growth in Rats

Dunlop, M.; Court, J.M 178

Metabolic Responses to Severe Perinatal Asphyxia in Term Newborn Infants with Particular

Reference to

the Changes in Plasma Free Amino Acids

Schultz, K.; Soltész, G.; Mestyán, J 185

Sequential Observation of Changes in Thyroxine, Triiodothyronine and Reverse

Triiodothyronine during

the Postnatal Adaptation of the Pig

Slebodziński, A.B.;Nowak, G.;Zamyslowska, H 191

Comparative in vivo and in vitro Effect of Mono- and Disaccharides on Intestinal Brush Border

Enzyme

Activities in Suckling Rats

Raul, F.; Kedinger, M.; Simon, P.M.; Grenier, J.F.; Haffen, K 200

Hormonal Status in the Newborn Lamb (Cortisol, T3, T4). Relationships to the Birth Weight and the

Length of Gestation: Effect of the Litter Size 
Cabello, G.; Levieux, D 208

No. 5-6

Alterations in Fetal Lung Phosphatidylinositol Metabolism Associated with Maternal Glucose Intolerance

Merritt, T.A.; Curbelo, V.; Gluck, L.; Clements, R.S.,Jr 217

Maturation of Early-Phase Insulin Release in the Neonatal Lamb

Philipps, A.F.;Dubin, J.W.;Raye, J.R 225

25-Hydroxyvitamin D3 Metabolism in the Pregnant Rat: Maternal-Fetal Relationships

Lester, G.E.; Gray, T.K.; Lorenc, R.S 232

Effect of Adrenalectomy on the Transmission of IgG in Young Rats

Morris, B.; Morris R.; Kenyon,C.J 239

IV

Contents

Phenytoin Administration to Pregnant Mice: a Mutagenic Action?

Petter,C; Lombard, M.-N.; Ehrensperger, M 246

Skeletal Muscle Development in the Fetal Pig after Decapitation in utero

Campion, D.R.; Hausman, G.J.; Richardson, R.L 253

Relationship of Mitochondrial Phosphoenolpyruvate Carboxykinase to Neonatal

Gluconeogenesis

Parameswaran, M.; Arinze, I.J 260

Surfactant Phospholipid Ontogeny in Fetal Rabbit Lung Lavage and Amniotic Fluid

Torday, J.S.; Nielsen, H.C 266

Somatic Growth and Brain Development. Effects of Intrauterine Malnutrition and Hypoxia in

Mice

Meberg, A 272

A Comparison of the in vivo Metabolism of Phenothiazine and Promazine in the Neonatal

Guinea Pig

Mitchell, S.C.; Waring, R.H 285

Transient Apnea after an Enkephalin Analogue in the Preterm Rabbit

Hedner, T.;Hedner, J.; Bergman, B.; Lundberg, D 290

Effects of Phototherapy on Serum Unbound Bilirubin in Icteric Newborn Infants

Nakamura, H.; Lee, Y.;Uetani, Y.; Kitsunezuka, Y.; Shimabuku, R.;Matsuo, T

295

Lipids in Forehead Vernix from Newborn Infants

Wysocki, S.J.;Grauaug, A.; O’Neill, G.;Hähnel, R 300

Localization of Tamm-Horsfall Glycoprotein in the Fetal and Neonatal Hamster Kidney as

Demonstrated by Immunofluorescence and Immunoelectron Microscopical Techniques

Sikri, K.L.; Foster, C.L.; Alexander, D.P.; Marshall, R.D 305

Author Index 313

Subject Index 314

Drug Dosage

The authors and the publisher have exerted every effort to ensure that drug selection and dosage set forth in this text are in accord with current recommendations and practice at the time of publication. However, in view of ongoing research, changes in government regulations, and the constant flow of informa-

tion relating to drug therapy and drug reactions, the reader is urged to check the package insert for each drug for any change in indications and dosage and for added warnings and precautions. 
This is particularly important when the recommended agent is a new and/or infrequently employed drug.

\section{S. Karger AG,}

P.O. Box, O↔009 Basel (Switzerland)

Printed in Switzerland by Thür AG Offsetdruck, Pratteln

All rights reserved.

No part of this publication may be translated into other languages, reproduced or utilized in any form or by any means, electronic or mechanical, including photocopying, recording, microcopying, or by any information storage and retrieval system, without permission in writing from the publisher. 